\title{
The chemistry of Brazilian Leguminosae. LX. Indolylacetic acid from Tachigalia paniculata
}

\author{
Silvia M. C. Dias; (') José G. S. Maia; $\left(^{2}\right)$ Zenaide S. Ferreira ( $\left.{ }^{3}\right)$ e Otto R. Gottlieb $\left({ }^{3}\right)$
}

\begin{abstract}
The ethanolic extract of trunk wood of Tachigalia paniculata Ducke (Leguminosae-Caesalpinioideae) was found to contain substantial quantities of 2-(3-indolyl). acetic acid.
\end{abstract}

\section{INTRODUCTION}

Tachigalia Aubl., a small genus of the tribe Caesalpinieae, subfamily Leguminosae-Caesalpinioideae, comprises 24 species which occur in tropical Central and South America, mostly in Amazonia (Polhill \& Vidal, 1981). The sole chemical registry on the genus refers to $T$. paniculata Ducke, the inflorescences of which were reported to contain tryptamine and $\mathrm{N}$ methyltryptamine (Svoboda ct al., 1979). In continuation of our work on the chemistry of Leguminosae (for Part LIX see Braz Filho et al., 1980), a trunk wood sample, collected from a $T$. paniculata tree of the Ducke Forest Reserve near Manaus, was examined. To our surprise we were able to isolate from the ethanol extract, besides the common plant extractive sitosterol, only 2-(3-indolyl)-acetic acid.

\section{EXPERIMENTAL}

Isolation of the constituerts. Trunk wood of Tachigalia paniculata was reduced to powder $(5 \mathrm{~kg})$ and percolated with ethanol. The solvent was evaporated and the residue $(15 \mathrm{~g})$ was extracted in a soxhlet apparatus successively with benzene and ethyl acetate. Both solutions were evaporated The residue $(9 \mathrm{~g})$ of the benzone extraction was chromatographed on a column of silica gel $(200 \mathrm{~g})$. Elution with benzene, benzene - ethyl acetate $8: 2$ and ethyl acetate gave respectively aliphatic esters, sitosterol and indolylacetic acid. The residue $(3.6 \mathrm{~g})$ of the ethyl acetate extraction was chromatographed on a column of silica gel $(110 \mathrm{~g})$. Elution with chloroform and benzene - ethyl acetate 8:2 gave respectively sitosterol and indolylacetic acid. Totals obtained : aliphatic esters $3 \mathrm{~g}$, sitostero! $1.5 \mathrm{~g}$, indolylacetic acid $100 \mathrm{mg} \mathrm{(20} \mathrm{ppm,} \mathrm{calculated} \mathrm{on}$ wood) .

2-(3-Indo/yl)-acetic acid, crystals, lit. mp (Merck Index, 1976) and $\mathrm{mp} 168-170^{\circ}$ (benzene - ethyl acetate). UV (Sadtler UV no 223), IR (Sadtler IR n' 670), 'H NMR (Sadtler NMR. 1198) and mass (Jamieson \& Hutzinger, (1970) spectra stiperimposable on analogous spectra given in the literature.

\section{Discussion}

Indolylacetic acid (heteroauxin) is a plant growth hormone which controls growth by promotion of cell elongation at the growing tip. Even stems, branches and trunks of woody plants, however. may be major sites of auxin synthesis, although they are rarely mentioned in standaid accounts of the subject (Little et al., 1978. Odani, 1970; Sheldrake, 1971; Shel. drake \& Northcote, 1968). While there is thus little doubt that the compound is widely distributed in plant tissue, it is equally clear that being a hormone, relatively small quantities (a few $\mu \mathrm{g} / \mathrm{kg}$ ) are highly efficient (van Overbeck, 1966; Galston \& Davies, 1969; Galston \& Purvas, 1960). This, added to the fact that it occurs in plants in different combined forms (Bandurski \& Schulze, 1977; Harborne, 1971) explains why it has so far been isolated only infrequently in normal phytochemical work.

\footnotetext{
(1) - Secretaria de Agricultura e Abastecimento do Estado de São Paulo, São Paulo, SP.

(2) - Instituto Nacional de Pesquisas da Amazônia, Manaus, AM.

( 3 ) - Universidade de São Paulo, São Paulo, SP.
} 
The unusual finding of $\mathrm{mg} / \mathrm{kg}$ quantities of indolylacetic acid in $T$. paniculata could a priori be due to artifact formation. Indeed, the compound can be produced during extraction of plant material either by hydrolysis of combined forms (Brenner, 1981), or by enzy. matic (Whitemore and Zahner, 1964) or sponianeous (Shantz, 1966) oxidation of tryptophan; and, as already stated above, T. paniculata is rich in tryptophan derived amines. Alternatively, epiphytic bacteria or fungi may introduce exogenous auxin into cellular tissue (Libbert et al., 1966; Pegg, 1976). This latter phenomenon is the most attractive racionalization of the present case. We have reported previously that wood samples, void of substantial quantities of autochthonous secondary metabolites, may contain a considerable gamut of fungal metabolites (Alvarenga et al., 1978) Thus also in $T$. paniculata the quantity of secondary metabolites may be too small for efficient defense against infestation by indolylacetic acid producing microorganisms.

\section{ACKNOWLEDGMents}

The authors are indebted to Coordenação do Aperfeiçoamento de Pessoal de Nível Superior (CAPES) and to Conselho Nacional de Desenvolvimento Científico e Tecnológico (CNPq) for fellowships, and to $\mathrm{Dr}$. Aderbal F. Magalhäes, Universidade Estadual de Cam. pinas, for mass spectra.

\section{RESUMO}

Do extrato etanólico da madeira de tronco de Ta. chigalia paniculata Ducke (Leguminosae-Caesalpinioideae) foram isoladas quantidades substanciais de ácido 2-(3-indolil)-acético.

\section{REFERENCES}

ALVARENGA, M.A. de; BRAZ FILHO, R.; GOTTLIEB, O.R.; MAGALHĀES, A.F.; MAGALHÃES, E.G.; MAGALHĀES, G.C.; MAGALHÃES, M.T.; MAIA, J.G.S.; MARQUES, R.; MARSAIOLI, A.J.; MORAIS, A.A. de; OLIVEIRA, A.B. de; OLIVEIRA, G.G. de; PEDREIRA, G.; PINHO, S.L.V.; SANT' ANA, A.E.G.; SANTOS, C.C.

1978 - Dihydroisocoumarins and phtalide from wood samples infested by fungi Phytochemistry, 17: 511-516.
BANDURSKI, R.S. \& SCHULZE, A.

1977 - Concentration of indole-3-acetic acid and its derivatives in plants. Plant Physiol., 60: 211. 213.

BRAZ FILHO, R.; FIGUEIREDO, U.S. de; GOTTLIEB, O.R. \& MOURÃO, A.P.

1980 - Rotenoids in Lonchocarpus Iongifolius. Acta Amazonica, 10: 843-844.

BRENNER, M.L.

1981 - Modern methods for plant growth substances analysis. Ann. Rev. Plant Physiol., 32: 511-538.

GALSTON, A.W. \& DAVIES, P.J.

1969 - Hormonal regulation in higher plants. Science, 163: 1288-1297.

GALSTON, A.W. \& PURVES, W.K.

1960 - The mechanism of action of auxin. Ann. Rev. Plant Physiol., 11: 239-276.

HARBORNE, J.B.

1971 - Terpenoid and other low molecular weight substances of systematic interest in the Leguminosae. In: J.B. Harborne, D. Boulter \& B.L. Turner, eds. Chemotaxonomy of the Leguminosae, pp. 257-283, Academic Press, London.

JAMIESON, W.D. \& HUTZINGER, O.

1970 - Identification of simple naturally occurring indoles by mass spectrometry. Phytochemistry, 9: 2029-2036.

LIBBERT, E.; WICHNER, S.; SCHIEWER, U.; RISCH, H.; KAISER, W.

1966 - The influence of epihytic bacteriae on auxin metabolism. Planta, 68: 327-334.

LITTLE, C.H.A.; HEALD, J.K.; BROWNING, G.

1978 - Identification and measurement of indoleacetic and abscisic acids in the cambial region of Picea sitchensis (Bong.) Carr. by combined gas chromatography - mass spectrometry. Planta, 139: 133-138.

MERCK INDEX

1976 - An encyclopedia of chemicals and drugs, 9. ed., p. 656. Rahway.

ODANI, $\mathrm{K}$.

1970 - Detection of IAA in cambial zone of Pinus densiflora. Mokuzai Gakkaishi, 16: 353-355; apud Chem. Abstr. 75: 31207 (1971).

OVERBEEK, J. VAN

1966 - Plant hormones and regulators. Science, 152: $721-731$.

PEGG, G.F.

1976 - Endogenous auxin in healthy and diseased plants. In: P.H. Williams \& R. Heitefuss, eds., Physiological Plant Pathology. pp. 560581, Springer, Heidelberg. 
POLHILL, R.M. \& VIDAL, J.E.

1981 - Caesalpinieae. In R.M. Polhill \& P.H. Raven, eds., Advances in Legume Systematics, Part 1. p. 88, Royal Botanic Gardens, Kew.

SADTLER STANDARD SPECTRA

1962-1966 - Sadtler Research Laboratories Inc,, Philadelphia.

SHANTZ, E.M.

1966 - Chemistry of naturally-occurring growthregulating substances. Ann. Rev. Plant. Physiol., 17: 409-438.

SHELDRAKE, A.R.

1971 - Auxin in the cambium and its differentiating derivatives. J. Exp. Bot., 22: 735-740.
SHELDRAKE, A.R. \& NORTHCOTE, D.H.

1968 - Some constituents of xylem sap and their possible relationship to xylem differentiation. J. Exp. Bot., 19: 681-689.

SVOBODA, K.S.; SMOLENSKI, S.J.; KINGHORN, A.D.

1979 - Indole alkylamines from Tachigalia paniculata. J. Nat. Prod. (Lloydia), 42: 309-310.

WHITMORE, F.W. \& ZAHNER, R.

1964 - Indoleacetic acid synthesis by polyphenols in the extraction of Pinus phloem and cambial tissue. Science, 145: 166-167.

(Aceito para publicação em $08 / 11 / 82$ ) 